\title{
Living with Climate Change: Assessment of the Adaptive Capacities of Smallholders in Central Rift Valley, Ethiopia
}

\author{
Zenebe Mekonnen $^{1}$ (D), Habtemariam Kassa ${ }^{2}$ \\ ${ }^{1}$ Wondo Genet College of Forestry and Natural Resources, Hawassa University, Shashemene, Ethiopia \\ ${ }^{2}$ Forests and Livelihoods Research, Centre for International Forest Research (CIFOR), Addis Ababa, Ethiopia \\ Email: zenebemg2014@gmail.com,h.kassa@cgiar.org
}

How to cite this paper: Mekonnen, Z. and Kassa, H. (2019) Living with Climate Change: Assessment of the Adaptive Capacities of Smallholders in Central Rift Valley, Ethiopia. American Journal of Climate Change, 8, 205-227.

https://doi.org/10.4236/ajcc.2019.82012

Received: December 18, 2018

Accepted: May 21, 2019

Published: May 24, 2019

Copyright () 2019 by author(s) and Scientific Research Publishing Inc. This work is licensed under the Creative Commons Attribution International License (CC BY 4.0).

http://creativecommons.org/licenses/by/4.0/

\begin{abstract}
Farms less than 2 hectares have constituted almost $90 \%$ of the total number of farms in Ethiopia. These small farms are rain fed and are vulnerable to climate change and variability extremes such as droughts. This in turn undermined the ability of smallholders' farmers to feed themselves and the growing population. A questionnaire survey was conducted with a random sample of 355 smallholder farmers distributed in three agro-ecologies, namely, lowland, midland, and highland in central rift valley of Ethiopia (Arsi Negele district). This was supplemented with 18 focus group discussions and 30 key informant interviews. How do smallholder farmers live with climate change and variability challenges? On the basis of this question, this study has assessed the factors that determine the adaptive capacities, strategies and livelihoods of smallholders to climate change and variability; and the role of climate capacities and landscape functions for sustainable adaptation in response to climate change and variability. The results showed that even if most respondents ( $>95 \%$ ) have the perception and intention of climate change; it was nearly $3 \%$ of them have higher adaptive capacity to adapt to climate change impacts. Adaptive capacity of smallholders and the potential impact exerted by climate change risks were negatively correlated $(\mathrm{r}=-0.134$ and $\mathrm{p}<0.02)$. The results showed that farmers have made some evolution in their livelihoods as an adaptation strategy. Adaptation strategies explicitly depend on adaptive capacity-human, natural, financial, social and physical resources. Indeed, the results indicated limited climate-specific and climate-relevant capacities at the local level which suggests a need to strengthen climate capacities. Moreover, it has been implicated that maintaining the landscapes, which provide landscape production functions that build the well-being and adaptive capacity of farmers, could help to sustain farmers' livelihood and build their adaptive capacity to withstand the challenges of climate change.
\end{abstract}




\section{Keywords}

Adaptation, Climate Capacity, Income Inequality, Potential Impacts, Landscapes Functions, Smallholder

\section{Introduction}

Ethiopia is an agrarian country at which most of its agriculture is practiced by smallholder farmers to feed the population. This practice is particularly vulnerable to climate change and variability extremes such as droughts [1]. Climate change is undermining the ability of smallholder farmers to feed themselves by welfare losses. Farmers have accustomed to modifying their agricultural practices to deal with climate change and variability impacts [2] [3]. However, these farmers' practices have been overlooked from policy and extension [4] rather than integrating them with modern agricultural practices in order to bring more robust adaptation against the impact of climate change and variability [5] [6]. Climate change is a development issue for Ethiopia and as a result the country has set climate resilient green economy strategy to meet its goal of becoming a middle-income country by 2025 [7].

To lessen the impacts of climate change and variability extremes, smallholder farmers need to have the recognition of climate change that is already taking place and undertake appropriate intervention in adaptation in order to live with the changes. A portfolio of adaptation strategies alone without the amalgamation of technological development and research, combined policies and actions at multiple scales, and integrated governance between public, private and civic institutions cannot withstand risks of climate change [8] [9].

Smallholders, as the name indicates, are farmers who lead their livelihood on small farms. These farms, when summed up, accounted for more than $80 \%$ of the world's total farms [10]. In Ethiopia, where farms smaller than 2 hectares constitute almost $90 \%$ of the total number of farms [11], small farms are very fragmented and are mostly rain-fed. The land ownership distribution in Ethiopia ranged from 0.12 ha for the bottom quartile to 2.53 ha for the top quartile with respective productivity distribution of USD 3.13-444.01 [12]. This was very small as compared to other African countries. A knock on impact of changes in extreme weather events on crop and animal productivity, food security, income and overall well-being combined with the low affluence of smallholder farmers to adapt to an impact has made them more vulnerable. To curb the impacts of climate change and variability that smallholder farmers face, Ethiopia should design an adaptation policy that overlies with the principles of sustainable adaptation [13] [14] (Figure 1). This, with capable institutions, could provide stable conditions and support for making the livelihood assets of smallholder farmers more resilient to climate change [15] [16]. However, there was imbalance of credence between mitigation and adaptation at the COPs meetings until Lima 


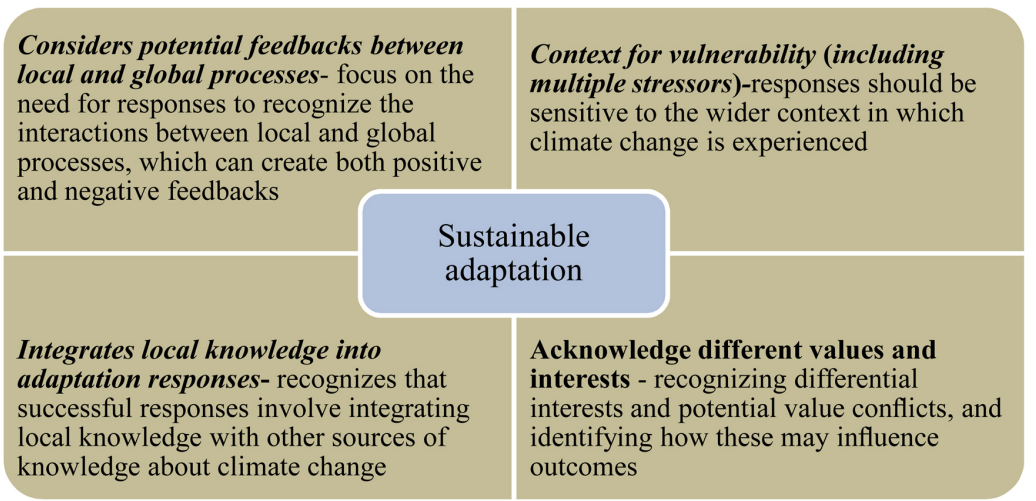

Figure 1. The cornerstones of sustainable adaptation (adapted: [13] [14]).

2014 by giving more weight to mitigation. This international inclination also influences individual nation's climate change policy to incline towards the same path [17]. And this national action has similar impact when devolved to local levels.

Smallholder farmers' livelihood has been triggered by land degradation [17] [18] [19] [20], deforestation [21] and loss of biodiversity [22]. This requires an integrated farming landscape management and an ecosystem based adaptation approaches to enhance smallholders' resilience to climate change and variability impacts.

There are studies in Ethiopia that have dealt on the determinants of adaptation choice of smallholder farmers [23]-[28]. There were also government initiatives such as the Growth and Transformation Plans I and II and the Climate Resilient Green Economy strategy of Ethiopia which aimed to boost smallholder farmers' production and making agriculture green [29]. Indeed, landscape functions and the variation across agro-ecologies, existing interventions and their role in climate change adaptation and mitigation, and their sustainability from institutional, economic and environmental perspectives to enhance smallholder farmers' livelihoods is not well documented. This particular study, however, was aimed at to assess the determinants of adaptive capacity of smallholder farmers which also determine the choice of an adaptation strategy by smallholder farmers. It also aimed at how landscape functions and climate capacities are influencing the adaptive capacity of farmers.

\section{Material and Methods}

\subsection{The Study Area}

The study was conducted in Arsi-Negele district which is located in West Arsi zone of the Oromia Regional State, Ethiopia. The district is located between $7.15^{\circ} \mathrm{N}-7.75^{\circ} \mathrm{N}$ latitudes and $38.35^{\circ} \mathrm{E}-38.95^{\circ} \mathrm{E}$ longitudes. The district's average annual temperature varied from $10^{\circ} \mathrm{C}-25^{\circ} \mathrm{C}$, while annual rainfall varied between $500-1000 \mathrm{~mm}$. The altitude of Arsi Negele district ranges from 1500 to 3000 meters above sea level. The topography encompasses the three lakes, namely, Langano, Shalla and Abijata in the central rift valley floor and extended to the eastern escarpment of the rift valley (Figure 2). 


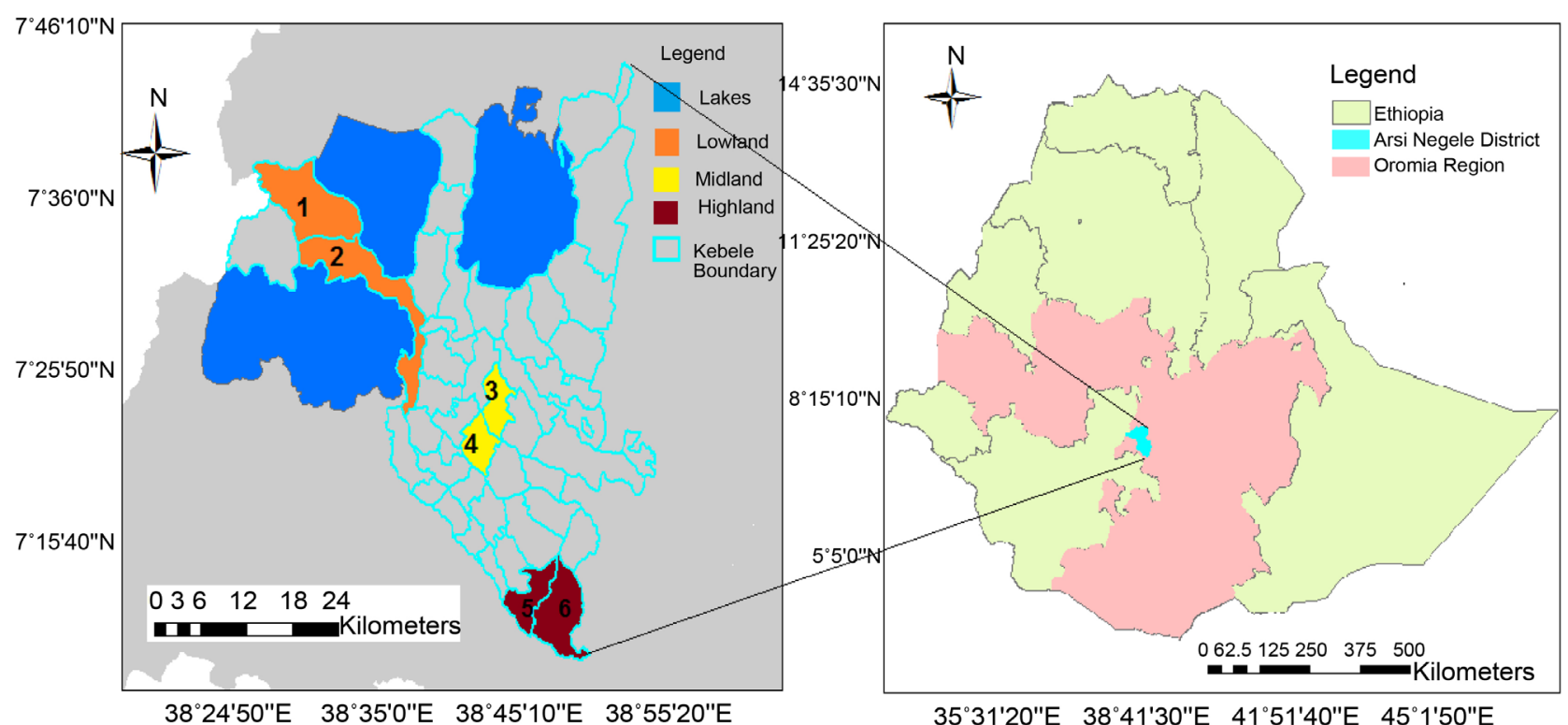

Figure 2. Map of the study area (Kebeles: 1 Mudi Arjo; 2 Shalla Billa; 3 Sirba Lenda; 4 Meko oda; 5 Meraro Hawilo and 6 Gode Duro).

According to Ethiopian Central Statistical Agency's (CSA) reports [30] [31], the total population of Arsi Negele district was 137,228; 198,307; 260,129 and 338,967 respectively (c and $\mathrm{p}$ indicating censuses and projections, respectively). These reports showed that the population of the district has increased by more than double between 1994 and 2016. The land forms in the study area cover flat slopes in the rift floor including four major lakes; and extend to the eastern escarpment of the central rift valley of Ethiopia with gentle slopes and mountains. The dominant soil types are andosols and nitosols [32]. The major livelihoods are crop cultivation (wheat, maize, tef) and livestock rearing (cattle, goats and sheep). The former dominates in the midland and highland agro-ecologies and the latter in the lowland agro-ecology. The forests in highland agro-ecology and the woodlands in lowland agro-ecology have been declined from time to time due to population growth, agricultural expansion and fuelwood collection [33].

\subsection{Sampling Design}

Arsi Negele district was purposely selected for the study based on the representativeness of lowland, midland and highland agro-ecologies. Six kebeles, the lowest administrative division in Ethiopia's geopolitical administration, two each from each agro-ecology, were selected after the reconnaissance survey of the district. From 4257 households in the six kebeles during the survey period, 355 were selected representing the population on the basis of normal distribution with confidence level of $95 \%$ and margin of error $5 \%$ followed by finite population correction (FPC) to get the true sample (i.e. $\mathrm{n}=(\mathrm{s} \times \mathrm{N}) /(\mathrm{s}+\mathrm{N}-1)$; where: $\mathrm{n}$ is true sample, $s$ is sample of $50 \%$ distribution $\sim 385, \mathrm{~N}=4257$ ) [34] [35]. Then proportional numbers of households at each kebele were randomly selected. 


\subsection{Data Collection}

Key informants interview. Farmers who are knowledgeable about their community situation, local natural resources, climate conditions, the culture of the community, overall development and the respective changes in these were selected by snowball method [36] [37]. And they were willing to share their built up knowledge and experience to the interviewer.

Household survey. A questionnaire survey was conducted with a random sample of 355 smallholder households distributed in three agro-ecologies, namely, lowland $(\mathrm{n}=104)$, midland $(\mathrm{n}=103)$, and highland $(\mathrm{n}=148)$ in Arsi Negele district, central rift valley of Ethiopia. The interviews were designed in semi-structured and structured forms and were translated into local language-Afan Oromo.

Focus group discussion: Three groups per kebele, at which each group consists of 8 - 10 peoples, were formed. The members of a group were selected purposely and were made to include women, elders and youth in order to obtain accumulated knowledge and views across these social groups. The focus group discussions have made use of participants' feelings, perceptions and opinion about local climate capacities, resource conditions, potential of interventions in the landscape for climate change adaptation and mitigation and their sustainability form ecological, economic and institutional dimensions, and landscape production functions. To rank a landscape as less or high relevant for a particular function, discussants have used numbers of farm plots and farmers engaged in crop farming to rank farming functions; numbers of livestock and herders engaged in livestock rearing to rank livestock husbandry functions; number of sacred places and potential recreation and tourism sites to rank cultural functions; numbers of hot spots areas and potential forests as water sources to rank conservation functions; and share of protected areas to rank habitation functions.

\subsection{Data Analysis}

Descriptive and econometric data analysis methods were used. Descriptive methods were used in the expression of household incomes, opinions of farmers in adaptation process and livelihoods evolution as well as adaptation strategies. The existing interventions in the landscape functions and benefits of landscape components were described qualitatively in the form of tables and diagrams. An econometric data analysis was applied to quantify the value estimates of the adaptive capacity indicators. Households were interviewed on what determines them to implement adaptation strategies against the impacts of climate change and variability. The explanatory variables $(n=23)$ which can determine the dependent variable (levels of adaptive capacity of households) were prioritized. The dependent variable was expressed in ordinal scale, while the explanatory variables can be continuous, dummy, ordinal or nominal. The multi-nominal logistic regression (MNLR) model was used to see the correlation of each expla- 
natory variable with the dependent variable as expressed by logistic Equation (1). The explanatory variables, which were scaled, have been normalized to calculate the adaptive capacity index of each household by PCA method.

$$
\operatorname{Logit}(Y)=\operatorname{LN}(P / 1-P)=\beta_{0}+\beta_{1} X_{1}+\beta_{2} X_{2}+\cdots+\beta_{n} X_{n}+\varepsilon_{i}
$$

where: $Y$ is the dependent variable (adaptive capacity); $\beta_{0}$ is the constant or the intercept of $Y ; \beta_{1}, \beta_{2} \cdots \beta_{n}$ are regression coefficients to be estimated; $X_{1}, X_{2} \cdots X_{n}$ are the independent variables (determinants of adaptive capacity); $P$ is the predicted probability of having a medium or higher adaptive capacity by a household for a particular determinant of adaptive capacity with the reference category of lower adaptive capacity; $1-P$ is the predicted probability of not having a medium or higher adaptive capacity by a household for a particular determinant of adaptive capacity with the reference category of lower adaptive capacity; ( $P / 1$ $-P$ ) is the odds ratio; $1,2,3, \cdots n$ is number of observations; and $\varepsilon_{i}$ is error term of the $i^{\text {th }}$ household. In addition to the MNLR analysis, binary logistic regression was used to determine the odd ratios of farmers' opinions in climate-relevant and climate-specific capacities at local level.

\section{Results}

\subsection{Adaptation Process and Adaptive Capacity}

Most of the respondent farmers in the study district, in all agro-ecologies, have percieved the rality of climate change and variability. More than $95 \%$ of the respondents have willingness and intention to adapt the climate change impacts. Neverthless, its nearly $60 \%$ of the respondents that have adaptive capacity to adapt climate change impacts (Figure 3). The majority of the farmers (74\%), in the highland agro-ecology, have adaptive capacity to adapt climate change and environmental risks. However, farmers with low and medium adaptive capacities have accounted $72 \%$ of this summation. And it was only $2.5 \%$ of the farmers have higher adaptive capacity in the highland agro-ecology. Farmers who have higher adaptive capacity in lowland and midland agro-ecologies have accounted only $5 \%$ and $1 \%$, respectively.

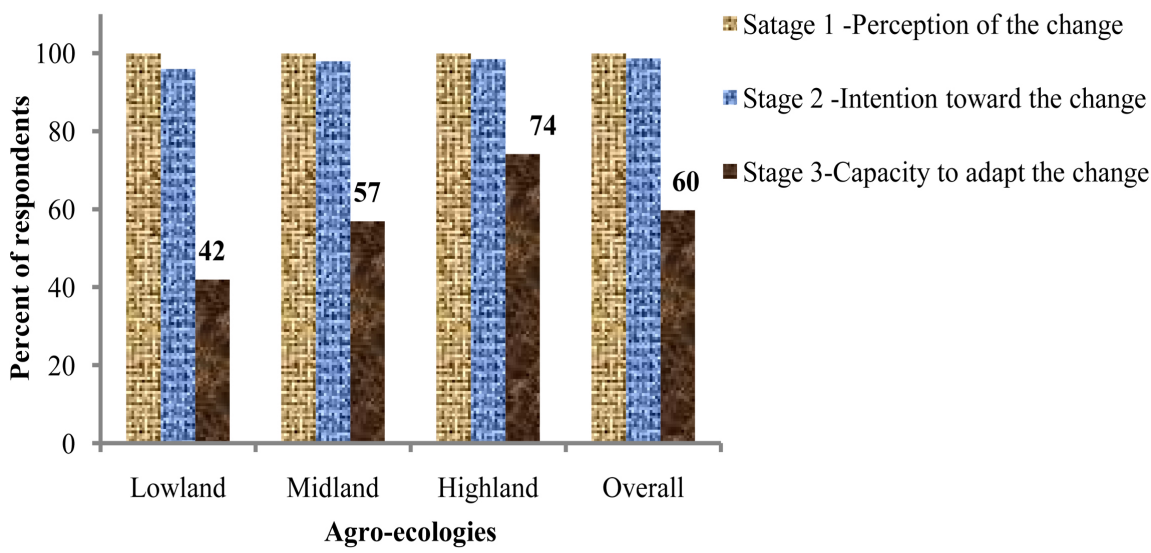

Figure 3. Adaptation stages in different agro-ecologies in Arsi Negele district. 
The results showed that adaptive capacity modulates farmers' vulnerability to climatic and environmental risks by lowering the potential impacts exerted by exposure and sensitivity. The impact score difference between potential impact (impact without adaptation) and residual impact (impact with adaptation) was the impact avoided by adaptation (Figure 4). Adaptive capacity of households and the potential impact exerted by climatic and environmental risks were negatively correlated $(r=-0.134$ and $p<0.02)$. That is, households with higher adaptive capacity were less impacted than those with low adaptive capacity. When the potential impact was higher, the residual impact was also higher $\left(r^{2}=0.99\right.$ and $\mathrm{p}<0.001)$.

\subsection{Adaptation Strategies}

Focus groups discussants and key informants explained that the 2015 El Niño event (extreme drought) has severely hit farmers' livelihood. It has caused death of crops before maturity, lead farmers to have low crop production, and at the same time it has caused death of livestock thereby farmers get low revenue and become more vulnerable to drought shocks. This was exacerbated by the lower scope of irrigation use by the farmers. The data sourced from the agriculture bureau of the district also showed that the production of major crops have been declined in 2015, with a total loss of 30,571.85 tonnes (17.4\%). The impacts of the loss of crop production and/or livestock vary between households. For instance, an asset loss of a cow due to drought has a higher impact on poor households than richer households. Focus group discussants and key informants have depicted that, richer households might loss more assets during drought episodes than the poor, however, in terms of livelihood impacts; it's the poor households that are highly hit. This implied that impacts are determined by adaptive capacity of a household. Households in different agro-ecologies adopted differnent adaptation strategies in order to maintain their livelihood from climatic shocks, such as drought. The potential adaptation strategies used by farmers include, but not limited to, crop diversification, use of improved seeds,

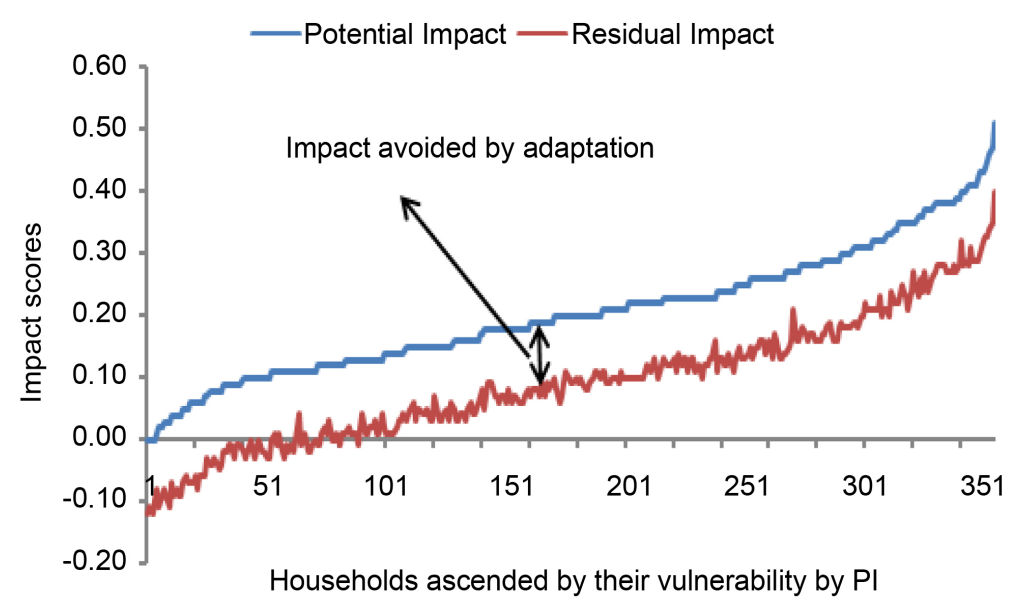

Figure 4. Adaptive capacity in modulating households' potential impacts. 
storing grain for hard time, shifting the crop sowing date with the shift of rainfall, tree planting and reforestation (Table 1).

\subsection{Livelihood Evolutions and Drivers}

Before thirty years ago, the opinions from focus group discussions, key informant interviews and household survey suggested that, households' main activity in the lowland agro-ecology was livestock rearing with local breeds. In the midland and highland, the main livelihood activity was mixed farming, which was also based on local livestock breeds and varieties of crops. In recent times, however, households in the lowland have become agro-pastoralist; even crop cultivation is going to dominate livestock rearing. In the midland and highland, food crop cultivation, which was mainly barley, is now dominated by market crop cultivation, such as tef, haricot bean and variety of vegetables. In both agro-ecologies, farmers have changed the use of local crop varieties with the use of improved varieties of crops, which are short maturing, productive and drought resistant. The rearing of local livestock breeds still dominates nowadays, but some farmers have shifted to improved breeds. Interviewees asserted that the most likely drivers in the shift of their livelihood to the new situation includes, but not limited to, climate change, good production, better market opportunity, good extension service and policy (Figure 5).

Table 1. Some of the prioritized adaptation strategies of farmers to climate change and variability impacts.

\begin{tabular}{|c|c|c|c|c|c|}
\hline \multirow[b]{2}{*}{ Adaptation strategies } & \multicolumn{4}{|c|}{ Percentage of respondents agreed "yes" } & \multirow{2}{*}{$\begin{array}{l}\text { Chi-square } \\
\quad\left(\chi^{2}\right)\end{array}$} \\
\hline & $\begin{array}{l}\text { Lowland } \\
(\mathrm{n}=104)\end{array}$ & $\begin{array}{l}\text { Midland } \\
(\mathrm{n}=103)\end{array}$ & $\begin{array}{l}\text { Highland } \\
(\mathrm{n}=148)\end{array}$ & $\begin{array}{c}\text { Total } \\
(\mathrm{N}=355)\end{array}$ & \\
\hline Crop diversification & 93 & 98 & 98 & 97 & $277.513^{\mathrm{a}}$ \\
\hline Use of improved seeds & 96 & 99 & 94 & 96 & $273.800^{\mathrm{a}}$ \\
\hline Use of improved livestock & 46 & 56 & 73 & 59 & $5.513^{\mathrm{a}}$ \\
\hline $\begin{array}{l}\text { Migrating to other area during } \\
\text { shocks }\end{array}$ & 69 & 57 & 46 & 57 & $110.450^{\mathrm{a}}$ \\
\hline Use of irrigation & 25 & 15 & 22 & 21 & $110.450^{\mathrm{a}}$ \\
\hline $\begin{array}{l}\text { Use of compost to boost crop } \\
\text { production }\end{array}$ & 94 & 89 & 77 & 86 & $227.813^{\mathrm{a}}$ \\
\hline $\begin{array}{l}\text { Use of fertilizer to boost crop } \\
\text { production }\end{array}$ & 39 & 98 & 97 & 79 & $108.113^{\mathrm{a}}$ \\
\hline Tree planting & 80 & 96 & 99 & 92 & $227.813^{\mathrm{a}}$ \\
\hline Storing grains for hard times & 96 & 100 & 95 & 97 & $281.250^{\mathrm{a}}$ \\
\hline Use of improved livestock feeds & 79 & 86 & 74 & 79 & $110.450^{\mathrm{a}}$ \\
\hline Use of water harvesting & 76 & 78 & 44 & 65 & $27.613^{\mathrm{a}}$ \\
\hline $\begin{array}{l}\text { Shift the crop sowing date with the } \\
\text { shift of rainfall }\end{array}$ & 100 & 100 & 90 & 96 & $273.800^{\mathrm{a}}$ \\
\hline Reforestation & 97 & 100 & 93 & 97 & $277.513^{\mathrm{a}}$ \\
\hline
\end{tabular}

a. No cells have expected frequencies less than 5 . The minimum expected cell frequency is 178 for the total. 


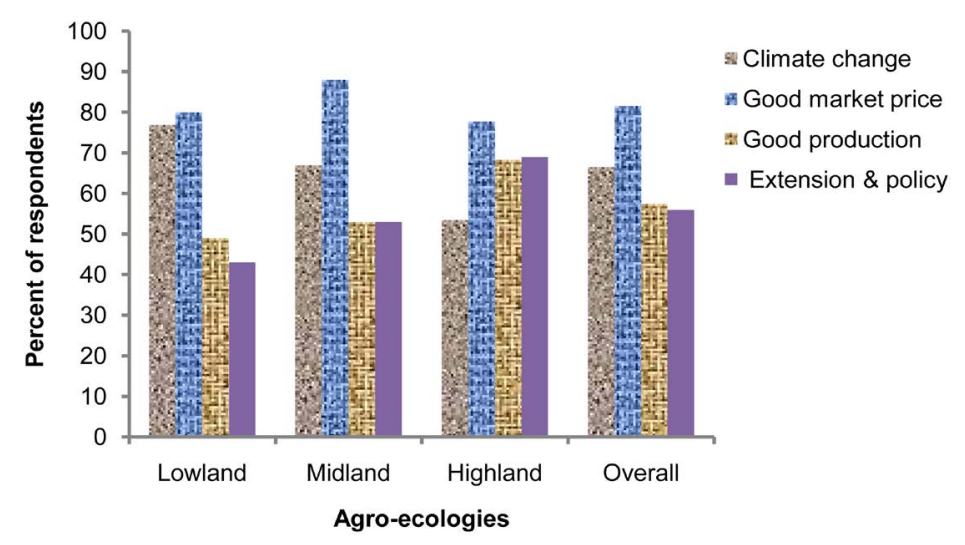

Figure 5. Major drivers of agricultural livelihood evolution in the study area (good production was steamed from better agricultural technologies based on modern research and development of new cultivars).

\subsection{Determinants of Adaptive Capacity}

As the results in Section 3.2 showed, farmers might have several adaptation strategies, but these strategies are explicitly depends on adaptive capacity. Say tree planting for example, depends on factors of adaptive capacity determinants, such as tenure security, access to land and finance. The adaptive capacities of households have been determined by human, natural, financial, social and physical resources, depending on the context of a particular agro-ecology (Table 2). On average, among the five domains of adaptive capacity indicators, human resource has contributed the highest share (47.33\%) to households' adaptive capacity, with the sub-indicators age of household head, farming experience and educational level of household head have contributed $9.31 \%, 10.35 \%$ and $10.2 \%$, respectively. The second highest contributor to households' adaptive capacity was the natural resource domain (34.46\%), by which the sub-indicators farm size and farm land soil fertility accounted $9.13 \%$ and $10.24 \%$, respectively. The F-test showed that there is no statistically significant difference in the contribution of the resource domains to households' adaptive capacity between agro-ecologies ( $p>0.05$ ), while the correlation is highly significant $\left(r^{2}=0.99, p<0.001\right)$.

The Econometric analysis of MNLR showed the likelihood ratio chi-square of 231.821 with a p-value $<0.001$. This shows that the model as a whole fits significantly better than a model with no predictions. In our model, the goodness-of-fit table also shows a non-significant $\mathrm{p}$-value of $0.921(\mathrm{p}<0.05)$, indicating the model fits the data well with $69.7 \%$ correct predictions. The model has displayed the parameter estimates (Table 3), and some of the estimates are interpreted as follows.

Age-A unit increase in the variable age was associated with a 0.09 decrease in the relative log odds of being in higher adaptive capacity vs. lower adaptive capacity, and a 0.045 increase of being in medium adaptive capacity vs. lower adaptive capacity. The relative risk ratio for a unit increase in the variable age was 0.914 for being in higher adaptive capacity vs. lower adaptive capacity, and was 1.046 for being in medium adaptive capacity vs. lower adaptive capacity. 
Table 2. Factors affecting household's adaptive capacity in the study area (+sign positive influence, -sign negative influence; \pm sign conditionally influence either positively or negatively).

\begin{tabular}{|c|c|c|c|c|}
\hline $\begin{array}{l}\text { Adaptive } \\
\text { Capacity } \\
\text { indicators }\end{array}$ & $\begin{array}{c}\text { Prioritized adaptive capacity } \\
\text { sub-indicators }\end{array}$ & description & $\begin{array}{l}\text { Direction } \\
\text { of influence }\end{array}$ & $\begin{array}{c}{ }^{1} \text { Contribution to } \\
\text { household's } \\
\text { adaptive } \\
\text { capacity }(\%)\end{array}$ \\
\hline \multirow{6}{*}{$\begin{array}{l}\text { Human } \\
\text { capital }\end{array}$} & Age of household age & Years (continuous) & \pm & 9.31 \\
\hline & Farming experience & $\begin{array}{l}\text { Years in farming } \\
\text { (continuous) }\end{array}$ & + & 10.35 \\
\hline & Education & $\begin{array}{l}\text { Years of schooling } \\
\text { (continuous) }\end{array}$ & + & 10.17 \\
\hline & Place attachment ratio & $\begin{array}{l}\text { Time lived in an } \\
\text { area/age (continuous) }\end{array}$ & - & 5.45 \\
\hline & Gender & $\begin{array}{l}1 \text { male, } 0 \text { Female } \\
\text { (Nominal) }\end{array}$ & \pm & 2.82 \\
\hline & $\begin{array}{l}\text { Willingness \& planning to } \\
\text { adapt }\end{array}$ & 1 yes, 0 no (dummy) & + & 9.23 \\
\hline \multirow{4}{*}{$\begin{array}{l}\text { Natural } \\
\text { capitals }\end{array}$} & Farm size & Hectare (continuous) & + & 9.13 \\
\hline & Access to irrigation water & 1 yes, 0 no (dummy) & + & 8.35 \\
\hline & Farmland soil fertility & $\begin{array}{l}0 \text { infertile, } 1 \text { low, } 2 \\
\text { medium, } 3 \text { high }\end{array}$ & \pm & 10.24 \\
\hline & Access to forest resources & 1 yes, 0 no (dummy) & + & 6.74 \\
\hline \multirow{3}{*}{$\begin{array}{l}\text { Financial } \\
\text { capital }\end{array}$} & Credit and saving & 1 yes, 0 no (dummy) & + & 0.76 \\
\hline & $\begin{array}{l}\text { Total income (farm \& } \\
\text { non-farm) }\end{array}$ & Birr (continuous) & + & 1.05 \\
\hline & Livelihood diversity index & Index 0 - 1 (continuous) & + & 1.22 \\
\hline \multirow{5}{*}{$\begin{array}{l}\text { Social } \\
\text { capital }\end{array}$} & $\begin{array}{l}\text { Membership in insurance } \\
\text { scheme }\end{array}$ & 1 yes, 0 no (dummy) & + & 1.37 \\
\hline & Training on climate variation & 1 yes, 0 no (dummy) & + & 1.24 \\
\hline & $\begin{array}{l}\text { Membership in farm } \\
\text { organization }\end{array}$ & 1 yes, 0 no (dummy) & + & 1.07 \\
\hline & Land certification & $\begin{array}{l}1 \text { certified, } 2 \text { uncertified } \\
\text { (Nominal) }\end{array}$ & + & 4.06 \\
\hline & $\begin{array}{l}\text { Integration of different } \\
\text { approaches in climate } \\
\text { change adaptation }\end{array}$ & $\begin{array}{l}1 \text { high, } 2 \text { low, } 3 \text { no } \\
\text { (Ordinal) }\end{array}$ & \pm & 1.97 \\
\hline \multirow{3}{*}{$\begin{array}{l}\text { Physical } \\
\text { capital }\end{array}$} & Access to market & 1 yes, 0 no (dummy) & + & 2.07 \\
\hline & Access to health care & 1 yes, 0 no (dummy) & + & 1.10 \\
\hline & Access to farm inputs & 1 yes, 0 no (dummy) & + & 2.30 \\
\hline
\end{tabular}

Note: Birr is Ethiopian currency ( 1 USD $\approx 21$ Birr in 2015).

Gender-The relative log odds of being in higher adaptive capacity vs. lower adaptive capacity will increase by 1.024 , of being a $\mathrm{MHH}$ [gender $=1.00$ ] than of ${ }^{1}$ Only from the prioritized adaptive capacity sub-indicators in the context of the study area. 
Table 3. Determinants of the adaptive capacities of households and their estimates from the multinomial logistic regression outputs.

\begin{tabular}{|c|c|c|c|c|c|c|c|c|c|c|c|c|}
\hline \multirow{3}{*}{ Variables } & \multicolumn{12}{|c|}{ Households adaptive capacity ${ }^{a}$} \\
\hline & \multicolumn{6}{|c|}{ Higher vs. lower adaptive capacity } & \multicolumn{6}{|c|}{ Medium vs. lower adaptive capacity } \\
\hline & B & S.E. & Wald & df & Sig. & $\operatorname{Exp}(B)$ & B & S.E. & Wald & df & Sig. & $\operatorname{Exp}(B)$ \\
\hline Intercept & 3.431 & 3.009 & 1.300 & 1 & 0.254 & & 2.492 & 2.293 & 1.181 & 1 & 0.277 & \\
\hline Age & -0.090 & 0.047 & 3.668 & 1 & 0.055 & 0.914 & 0.045 & 0.030 & 2.236 & 1 & 0.135 & 1.046 \\
\hline Landsz & 0.402 & 0.211 & 3.625 & 1 & 0.057 & 1.495 & 0.233 & 0.180 & 1.666 & 1 & 0.197 & 1.262 \\
\hline LDI & -2.423 & 2.334 & 1.078 & 1 & 0.299 & 0.089 & -0.678 & 1.797 & 0.142 & 1 & 0.706 & 0.508 \\
\hline Education & 0.016 & 0.076 & 0.046 & 1 & 0.830 & 1.016 & 0.028 & 0.060 & 0.216 & 1 & 0.642 & 1.028 \\
\hline Farmexp & 0.101 & 0.051 & 3.859 & 1 & 0.049 & 1.106 & -0.047 & 0.036 & 1.689 & 1 & 0.194 & 0.954 \\
\hline PAR & -0.413 & 1.713 & 0.058 & 1 & 0.809 & 0.662 & -0.437 & 1.267 & 0.119 & 1 & 0.730 & 0.646 \\
\hline$[$ Gender $=0.00]$ & 1.024 & 0.718 & 2.033 & 1 & 0.154 & 2.785 & 0.166 & 0.616 & 0.073 & 1 & 0.787 & 1.181 \\
\hline$[$ Gender $=1.00]$ & $0^{\mathrm{b}}$ & & & 0 & & & $0^{\mathrm{b}}$ & & & 0 & & \\
\hline$[$ Landcert $=1.00]$ & -2.108 & 0.648 & 10.581 & 1 & 0.001 & 0.121 & -1.097 & 0.508 & 4.664 & 1 & 0.031 & 0.334 \\
\hline [Landcert $=2.00]$ & -0.475 & 0.791 & 0.360 & 1 & 0.549 & 0.622 & -0.565 & 0.684 & 0.682 & 1 & 0.409 & 0.569 \\
\hline$[$ Landcert $=3.00]$ & $0^{\mathrm{b}}$ & & & 0 & & & $0^{\mathrm{b}}$ & & & 0 & & \\
\hline [Integration_Drisk = 1.00] & 1.606 & 1.089 & 2.176 & 1 & 0.140 & 4.981 & -0.394 & 0.996 & 0.156 & 1 & 0.693 & 0.675 \\
\hline [Integration_Drisk $=2.00$ ] & 0.929 & 0.528 & 3.099 & 1 & 0.078 & 2.532 & 0.114 & 0.418 & 0.075 & 1 & 0.784 & 1.121 \\
\hline [Integration_Drisk = 3.00] & $0^{\mathrm{b}}$ & & & 0 & & & $0^{\mathrm{b}}$ & & & 0 & & \\
\hline [Acc_irrigation $=0.00]$ & -0.215 & 0.936 & 0.053 & 1 & 0.818 & 0.806 & -1.615 & 0.699 & 5.330 & 1 & 0.021 & 0.199 \\
\hline [Acc_irrigation $=1.00]$ & $0^{\mathrm{b}}$ & & & 0 & & & $0^{\mathrm{b}}$ & & & 0 & & \\
\hline [Acc_Forests $=0.00]$ & -1.446 & 0.660 & 4.797 & 1 & 0.029 & 0.235 & -1.260 & 0.460 & 7.504 & 1 & 0.006 & 0.284 \\
\hline [Acc_Forests = 1.00] & $0^{\mathrm{b}}$ & & & 0 & & & $0^{\mathrm{b}}$ & & & 0 & & \\
\hline$[$ Acc_credit $=0.00]$ & -0.388 & 0.533 & 0.528 & 1 & 0.468 & 0.679 & -0.141 & 0.423 & 0.110 & 1 & 0.740 & 0.869 \\
\hline$[$ Acc_credit $=1.00]$ & $0^{\mathrm{b}}$ & & & 0 & & & $0^{\mathrm{b}}$ & & & 0 & & \\
\hline$[$ Saving $=0.00]$ & -0.323 & 0.679 & 0.226 & 1 & 0.635 & 0.724 & -0.583 & 0.498 & 1.372 & 1 & 0.241 & 0.558 \\
\hline$[$ Saving $=1.00]$ & $0^{\mathrm{b}}$ & & & 0 & & & $0^{\mathrm{b}}$ & & & 0 & & \\
\hline$[$ Insurance $=0.00]$ & -1.397 & 0.535 & 6.819 & 1 & 0.009 & 0.247 & -0.454 & 0.402 & 1.275 & 1 & 0.259 & 0.635 \\
\hline$[$ Insurance $=1.00]$ & $0^{\mathrm{b}}$ & & & 0 & & & $0^{\mathrm{b}}$ & & & 0 & & \\
\hline$[$ Training $=0.00]$ & 0.259 & 0.701 & 0.136 & 1 & 0.712 & 1.296 & -0.112 & 0.559 & 0.040 & 1 & 0.841 & 0.894 \\
\hline [Training $=1.00]$ & $0^{\mathrm{b}}$ & & & 0 & & & $0^{\mathrm{b}}$ & & & 0 & & \\
\hline$[$ Market $=0.00]$ & -0.758 & 1.210 & 0.392 & 1 & 0.531 & 0.469 & -0.358 & 0.841 & 0.181 & 1 & 0.671 & 0.699 \\
\hline$[$ Market = 1.00] & $0^{\mathrm{b}}$ & & & 0 & & & $0^{\mathrm{b}}$ & & & 0 & & \\
\hline
\end{tabular}

${ }^{a}$ The reference category is lower adaptive capacity. ${ }^{b}$ This parameter is set to zero because it is redundant. Note: $\mathrm{R}^{2}=0.514$ (Cox \& Snell), 0.587 (Nagelkerke). Model $\chi^{2}(56)=231.117, \mathrm{p}<0.001$.

being a $\mathrm{FHH}$ [gender $=0.00$ ], and will increase by 0.166 of being in medium adaptive capacity vs. lower adaptive capacity. The relative risk ratio for a $\mathrm{FHH}$ was 2.785 for being in higher adaptive capacity vs. lower adaptive capacity, and was 1.181 for being in medium adaptive capacity vs. lower adaptive capacity.

Integration of different risk management-The relative log odds of being in higher adaptive capacity vs. lower adaptive capacity will increase by 1.61 if a 
farmer uses the highest level of integration of different approaches in climate change adaptation [Integration_Drisk $=3.00$ ] than using the lowest level [Integration_Drisk $=1.00]$. The relative risk ratio of switching from the highest integration to the lowest was 4.981 for being in higher adaptive capacity vs. lower adaptive capacity. In other words, the expected risk of staying in the higher adaptive capacity was higher for households who use low level of integration.

Climate awareness - The relative log odds of being in higher adaptive capacity vs. lower adaptive capacity will increase by 0.259 if a household gets training on climate variation [training $=1.00$ ] than a household that did not get training on climate variation [training $=0.00$ ], and will decrease by 0.112 of being in medium adaptive capacity vs. lower adaptive capacity. The relative risk ratio for a household that did not get training on climate variation was 1.296 for being in higher adaptive capacity vs. lower adaptive capacity, and was 0.894 for being in medium adaptive capacity vs. lower adaptive capacity.

Access to irrigation-The relative log odds of being in higher adaptive capacity vs. lower adaptive capacity will decrease by 0.215 if a household has access to irrigation $[$ Acc_irrigation $=1.00$ ] than a household that has not access to irrigation $[$ Acc_irrigation $=0.00]$, and will decrease by 1.615 of being in medium adaptive capacity vs. lower adaptive capacity. The relative risk ratio for a household that has not access to irrigation was 0.806 for being in higher adaptive capacity vs. lower adaptive capacity, and was 0.199 for being in medium adaptive capacity vs. lower adaptive capacity.

Access to market-The relative log odds of being in higher adaptive capacity vs. lower adaptive capacity will decrease by 0.758 if a household has access to market $[$ Market $=1.00]$ than a household that has not access to market [Market $=0.00]$, and will decrease by 0.358 of being in medium adaptive capacity vs. lower adaptive capacity. The relative risk ratio for a household that has not access to market was 0.531 for being in higher adaptive capacity vs. lower adaptive capacity, and was 0.671 for being in medium adaptive capacity vs. lower adaptive capacity.

\subsection{Climate-Specific and Relevant Capacities}

Focus group discussants have affirmed that there were limited climate-specific capacities at local level (odds ratio $=0.335$ ), by which climate change adaptation initiatives are looked as side activity to other development program of the government. This type of development was perceived by farmers as it is not rapid, inclusive, and climate informed and will descend climate capacities. Focus group discussants also associated the lower climate capacities with the decline in average annual precipitation and increase of annual average temperature and frequency of weather events above or below the thresholds. In addition, they stated that decline in primary productivity (e.g. crop and livestock loss), per capita land resources and per capita output of land, per capita water resources and increase in economic loss have resulted in a decline of climate capacity. Similarly, focus 
group discussants mentioned that climate-relevant capacities were less likely (odds ratio $=0.118$ ) in the local level, except that there were good initiatives in watershed development. The results showed that focus groups that have agreed in the sufficiency of climate capacities in their locality were 0.204 times of the focus groups that haven't agreed in the sufficiency of climate capacities. This indicates that climate-specific and climate-relevant capacities at the study sites were associated with lower odds of outcome (Table 4).

Table 4. Agreement on climate specific and relevant-capacity by focus groups $(1=$ adequate, 2 = inadequate).

\begin{tabular}{|c|c|c|c|c|c|c|c|c|}
\hline \multirow{2}{*}{ Climate-specific capacity streams } & \multirow{2}{*}{ Likelihoods } & \multicolumn{2}{|c|}{ Agreement } & \multirow{2}{*}{ Total } & \multirow{2}{*}{$\mathrm{p}$} & \multirow{2}{*}{$\%$} & \multirow{2}{*}{ Odds } & \multirow{2}{*}{$\begin{array}{l}\text { Odds } \\
\text { ratio }\end{array}$} \\
\hline & & 1 & 2 & & & & & \\
\hline $\begin{array}{l}\text { Individual climate change skills of the } \\
\text { government staffs at local level }\end{array}$ & 1 & 3 & 15 & 18 & 0.167 & 16.7 & 0.200 & 0.040 \\
\hline $\begin{array}{l}\text { Organizational specific mandate on } \\
\text { climate change at local level }\end{array}$ & 1 & 1 & 17 & 18 & 0.056 & 5.6 & 0.059 & 0.003 \\
\hline $\begin{array}{l}\text { Level of co-operations among } \\
\text { organizations on climate change } \\
\text { issues at local level }\end{array}$ & 3 & 8 & 10 & 18 & 0.444 & 44.4 & 0.800 & 0.640 \\
\hline $\begin{array}{l}\text { Ability of mainstreaming climate } \\
\text { change issues into policy-making }\end{array}$ & 3 & 7 & 11 & 18 & 0.389 & 38.9 & 0.636 & 0.404 \\
\hline $\begin{array}{l}\text { Community knowledge } \\
\text { about climate change }\end{array}$ & 4 & 14 & 4 & 18 & 0.778 & 77.8 & 3.500 & 12.25 \\
\hline Subtotal & 2 & 33 & 57 & 90 & 0.367 & 36.7 & 0.579 & 0.335 \\
\hline \multicolumn{9}{|l|}{ Climate-relevant capacity streams } \\
\hline $\begin{array}{l}\text { Training opportunities to government } \\
\text { staff at local level }\end{array}$ & 1 & 2 & 16 & 18 & 0.111 & 11.1 & 0.125 & 0.016 \\
\hline $\begin{array}{l}\text { Compatibility of development and } \\
\text { climate change objectives of an } \\
\text { organization in the district }\end{array}$ & 2 & 5 & 13 & 18 & 0.278 & 27.8 & 0.385 & 0.148 \\
\hline $\begin{array}{l}\text { Integration of public practices and } \\
\text { policy }\end{array}$ & 2 & 5 & 13 & 18 & 0.278 & 27.8 & 0.385 & 0.148 \\
\hline Tenure security & 1 & 1 & 17 & 18 & 0.056 & 5.6 & 0.059 & 0.003 \\
\hline $\begin{array}{l}\text { Community attitude toward } \\
\text { environmental protection }\end{array}$ & 4 & 11 & 7 & 18 & 0.611 & 61.1 & 1.571 & 2.468 \\
\hline Subtotal & 2 & 24 & 66 & 90 & 0.267 & 26.7 & 0.343 & 0.118 \\
\hline Grand Total & 2 & 56 & 124 & 180 & 0.311 & 31.1 & 0.452 & 0.204 \\
\hline
\end{tabular}

Likelihoods: 1 = not likely, 2 = less likely, 3 = moderately likely, $4=$ likely, 5 = highly likely.

Forty-five percent of the respondents have agreed that collective actions are the best solutions to tackle climate change and variability risks at local level. About $6 \%$ of the respondents have suggested individual actions, while $49 \%$ of them have agreed on both actions combined. As compared to the situations of resource conditions before thirty years ago, the decline in forest, soil, water and biodiversity resources have been perceived by $98.8 \%, 97.2 \%, 96.6 \%$ and $92.2 \%$ of 
the respondents, respectively, i.e. the current natural capital in those resources is much less than the previous natural capital. This implies that climate-relevant capacities are declining from time to time in the study district. Thirty-two percent of the respondents have agreed that there was good institutional integration, while $68 \%$ of them have agreed that there was limited institutional integration towards adaptation planning in their local context.

\subsection{Landscape Functions for Climate Change Adaptation}

The results have shown that $90 \%$ of the income (subsistence + cash) for a household came from livestock (43.7\%), crop cultivation (34.3\%) and forest products $(12 \%)$. Nearly $60 \%$ of the forest income came from trees outside forests. It has been found that the Gini indices of forest and farm incomes were 0.6658 and 0.4717 , respectively. That mean, forest income distribution between households deviated by $66.58 \%$ from perfect equality, and farm income distribution deviated by $47.17 \%$ from perfect equality (Figure 6). Forest income distribution showed $19.41 \%$ higher deviation from perfect equality than farm income. Forests provided an average monetary value (excluding intangible values) of 31,279 birr (USD 1489.5) per household $\mathrm{yr}^{-1}$ for those households who have settled at $0 \leq \mathrm{D} \leq 2 \mathrm{~km}$ from a forest, and 2494 birr (USD 119) per household $\mathrm{yr}^{-1}$ for those who settled at $4<\mathrm{D} \leq 8 \mathrm{~km}$ from a forest (Table 5). On the other hand, agriculture provided an average monetary value of birr 40,454 (USD 1926.4) and 56,960 (USD 2712.4) for those respective distances of the same households. From FGDs and key informant interviews, it was understood that farmers that were settled nearer to a forest have extensive knowledge of the forest's content and gave high value to the forest so that making less deforestation pressure, while agricultural colonizers to forest have narrow knowledge of the forest's content but extensive knowledge of agriculture, and have created high

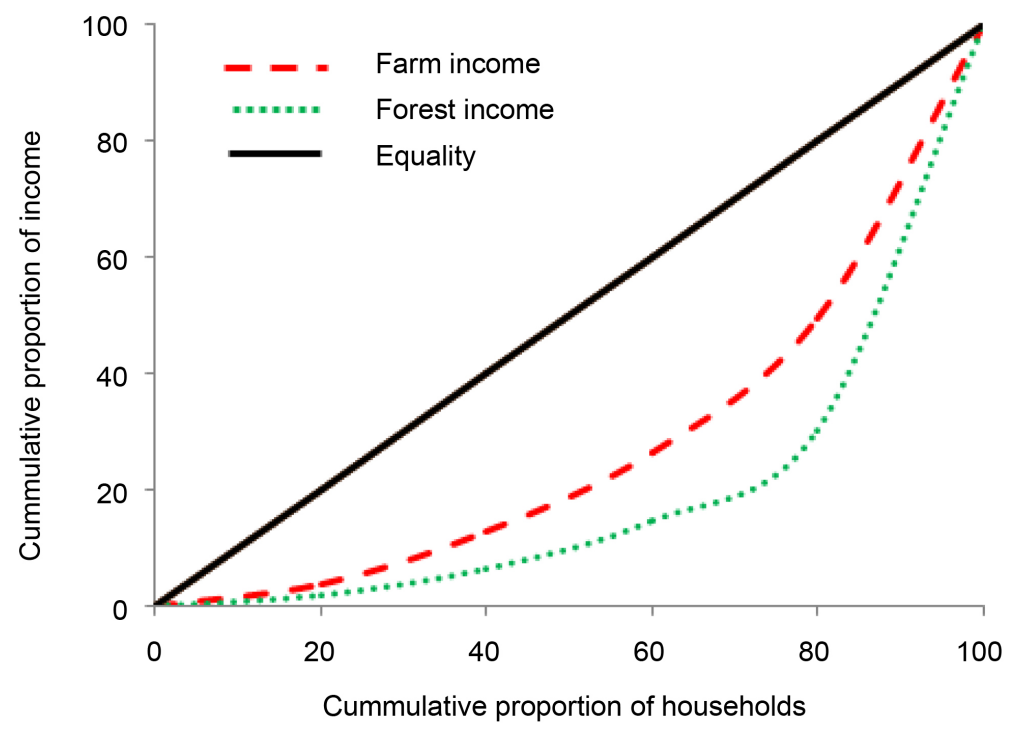

Figure 6. The Lorenz curve farm and forest incomes distribution among respondent households. 
Table 5. The relationship of households' forest and farm incomes with distance (D) from a forest.

\begin{tabular}{|c|c|c|c|c|}
\hline \multirow{2}{*}{$\begin{array}{c}\text { Distance } \\
\text { from a forest } \\
(\mathrm{km})\end{array}$} & \multirow{2}{*}{$\begin{array}{c}\% \text { of } \\
\text { sample } \\
\text { HHs }\end{array}$} & \multicolumn{3}{|c|}{ Average income/HH $\mathrm{yr}^{-1}$ (Eth Birr) } \\
\hline & & $\begin{array}{l}\text { Agricultural } \\
\text { income (a) }\end{array}$ & $\begin{array}{c}\text { Forest } \\
\text { income }(b)\end{array}$ & $\begin{array}{l}\text { Agriculture and forest } \\
\text { income }(c=a+b)\end{array}$ \\
\hline $0 \leq \mathrm{D} \leq 2$ & 5.4 & $40,554.00$ & $31,379.00$ & $71,933.00$ \\
\hline $2<\mathrm{D} \leq 4$ & 9.0 & $48,226.00$ & $12,196.00$ & $60,422.00$ \\
\hline $4<\mathrm{D} \leq 8$ & 85.6 & $56,960.00$ & 2494.00 & $59,454.00$ \\
\hline
\end{tabular}

$1 \mathrm{USD} \approx 21$ birr in 2015 .

deforestation pressure leading greater modifications in the forest matrix. These different values and interests affect adaptation outcomes of a household (Table 5). In this case, deforestation has a higher negative adaptation outcome for long-settled households at the forest edge than those far away.

Respondents have expressed that households near the forest edge are less impacted by climate variability because the forest can moderate the micro-climate for them; they have access to different forest products that can supplement their livelihoods including forest honey, medicinal plants, bush meat and wild edible fruits, and they have access to opportunities for recreation and ecotourism. On the other hand, households that are far away from forests have been deprived of such benefits.

The results of landscape assessments with key informants, FGDs and observation have shown that the major landscape attribute in the study area are crop farming, livestock husbandry, conservation, habitat and cultural functions. Farmers' comparisons of these attributes based on five-point scale have indicated the difference in the relevance of each function within and across agro-ecologies. For instance, in the lowland agro-ecology, a landscape has higher relevance for livestock husbandry and conservation functions; in the midland, for crop farming function, and in the highland, for crop farming and conservation functions. The productivity and sustainability of each function will be determined by how each component of the landscape is managed properly.

The results have shown that the sustainability of most of the interventions in the landscapes of the study sites was less likely, and would lead to maladaptation in the long-run (Table 6). Because the outcomes of these interventions in sustaining ecosystem services, improve livelihoods, enhance production and efficient resource use were low to medium levels. Besides, $68 \%$ of the respondents claimed that there was limited institutional integration towards adaptation planning and implementation.

\section{Discussions}

The study showed that different factors from each of the five capitals were found to determine the adaptive capacity of smallholder farmers which also determine the choice of an adaptation strategy by smallholder farmers which varied across 
Table 6. Observed interventions in the landscapes and their adaptation and mitigation potentials for climate change (Focus group discussants' opinion rankings).

\begin{tabular}{|c|c|c|c|c|c|c|c|}
\hline \multirow[t]{2}{*}{ Interventions } & \multicolumn{2}{|c|}{ Potential for } & \multirow[t]{2}{*}{ Key actors } & \multicolumn{3}{|c|}{$\begin{array}{c}\text { Sustainability } \\
\text { dimensions }\end{array}$} & \multirow[b]{2}{*}{ Overal } \\
\hline & CCA & $\mathrm{CCM}$ & & ID & ED & $\mathrm{SD}$ & \\
\hline $\begin{array}{l}\text { Forest management } \\
\text { - } \quad \text { Tree planting } \\
\text { - } \quad \text { Retaining trees on farm } \\
\text { - } \quad \text { Enclosure and restoration }\end{array}$ & iii & iv & $\begin{array}{l}\text { Smallholders } \\
\text { Communities }\end{array}$ & 2 & 3 & 4 & 3 \\
\hline $\begin{array}{l}\text { Soil \& Water Management } \\
\text { - water harvesting from } \\
\text { roof and flood } \\
\text { - Soil bund terracing }\end{array}$ & iii & iii & $\begin{array}{l}\text { Smallholders } \\
\text { Public and civic } \\
\text { organizations }\end{array}$ & 2 & 3 & 3 & 3 \\
\hline $\begin{array}{l}\text { Agricultural management } \\
\text { - New crop varieties } \\
\text { - } \quad \text { Crop rotation } \\
\text { - } \quad \text { New fodder varieties } \\
\text { - Intensification }\end{array}$ & iii & ii & $\begin{array}{l}\text { Smallholders } \\
\text { Research institutions } \\
\text { Public organizations }\end{array}$ & 2 & 3 & 4 & 3 \\
\hline $\begin{array}{l}\text { Alternative livelihoods } \\
\text { - } \quad \text { Fuelwood marketing } \\
\text { - } \quad \text { NTFPs marketing } \\
\text { - } \quad \text { Pole selling (eucalyptus) } \\
\text { - } \quad \text { Beekeeping } \\
\text { - } \quad \text { Vegetable production }\end{array}$ & iv & ii & $\begin{array}{l}\text { Smallholders } \\
\text { Public and civic } \\
\text { organizations }\end{array}$ & 2 & 2 & 4 & 3 \\
\hline $\begin{array}{l}\text { Energy initiatives } \\
\text { - Introducing improved } \\
\text { cooking stoves } \\
\text { - Solar dishes }\end{array}$ & iii & iv & $\begin{array}{l}\text { Smallholders } \\
\text { public \& civic } \\
\text { organizations }\end{array}$ & 3 & 3 & 3 & 3 \\
\hline $\begin{array}{l}\text { Governance initiatives } \\
\text { - } \quad \text { Land certification } \\
\text { - } \quad \text { Land use planning }\end{array}$ & ii & iii & $\begin{array}{l}\text { Smallholders } \\
\text { Public organizations }\end{array}$ & 2 & 2 & 2 & 2 \\
\hline
\end{tabular}

agro-ecologies. Indeed, it also showed that landscape functions and climate capacities are influencing the adaptive capacity of farmers. The results of this study showed that, most farmers (>95\%) have perceived climate change and have intention toward the change. However, it was very few of the farmers that have adaptive capacities to adapt the change. Farmers have adopted different adaptation strategies and manage the landscapes to avoid some of the potential climate change impacts so as to live with the changes. Indeed, farmers have made an evolution in their farming activities from traditional form to modern ones to make their livelihoods more sustainable. This was in line with other studies [38] [39]. The difference in adaptive capacities between agro-ecologies might be due to the level of exposure to climate change and variability and their sensitivity to that exposure as well as in the difference of the five capitals which determine adaptive capacities.

This study and other studies [40] [41] [42] indicated that to benefit from the 
values of landscapes, such as economic, natural and social values, it needs people and nature adapted management that integrate landscape planning approach which could be locally adapted, much focused to nature and people.

The study has identified different factors that affect adaptive capacity of smallholder farmers in the study area. The relative log odds of a household of being in higher adaptive capacity vs. lower adaptive capacity, and medium adaptive capacity vs. lower adaptive capacity have come out with $(+)$ or $(-)$ signs of different magnitudes. Also, the relative risk ratio for a household for a specific factor has come out with different risk magnitudes. The study showed that there were limited climate-specific (odds ratio $=0.34$ ) and climate-relevant (odds ratio $=$ 0.12) capacities in the study area. As shown in this study and others [43], climate-specific capacity can be steamed from, for instance, level of co-operations among organizations on climate change issues, ability of mainstreaming climate change issues into policy-making, and community knowledge about climate change. On the other hand, compatibility of development and climate change objectives of the government, integration of public practices and policy, and community attitude toward environmental protection are examples of climate-relevant capacity. Intervention in the landscape such as proper forest, agricultural, soil and water management and initiatives in alternative livelihoods, energy and good governance have double benefits in building adaptive capacity of smallholder farmers and resilience of the agro-ecology. This is in parallel to the study by Munthali and Murayama [44] that indicated the interdependences between smallholder farming and environmental management. Farmers responded that institutional integration, collective action and improvement of the declining resources conditions in the landscapes could help to bring higher odds of outcomes in climate-specific and climate-relevant capacities, and enable to build the resilience and adaptive capacity of farmers.

Ninety percent of the income for households in the study area was come from landscape production functions. Managing the landscapes, as this study showed, has dual benefits (Table 7). The study by Driscoll et al. [45] described that in extensively modified landscapes, how the landscape matrix is managed determines many conservation outcomes. On one hand, it helps to maintain and enhance ecosystem services such as water and soil protection and biodiversity as well as goods to sustain livelihood. On the other hand, it contributes to climate change adaptation by increasing productivity of landscapes, enhancing the resilience of agro-ecosystems, and reducing the vulnerability of rural communities [7] [46] [47]. These entail that appropriate landscape management is key adaptation measure [48]. The issues of food security, climate change adaptation and sustainable development all revolve around a sustainable management of landscapes [49] and hence community's resilience to climate change impacts.

Climate-smart landscape interventions as showed by this study, which encompasses climate-smart practices at the field and farm scale; management of land use interactions at landscape scale to achieve social, economic and ecological impacts; and diversity of land use across the landscape to provide resilience, 
Table 7. Benefits of components of landscape matrices in the study area.

\begin{tabular}{|c|c|c|c|}
\hline $\begin{array}{l}\text { Components of } \\
\text { landscape } \\
\text { matrix }\end{array}$ & Ecological benefits & $\begin{array}{l}\text { Socio-economic } \\
\text { benefits }\end{array}$ & $\begin{array}{l}\text { Implication for climate } \\
\text { change adaptation }\end{array}$ \\
\hline $\begin{array}{l}\text { Bamboo tickets } \\
\text { in the highland }\end{array}$ & $\begin{array}{l}\text {-Regulate } \\
\text { micro-climate } \\
\text {-Reduce soil erosion }\end{array}$ & $\begin{array}{l}\text {-Income generation } \\
\text {-House and fence } \\
\text { construction }\end{array}$ & $\begin{array}{l}\text { Builds resilience and } \\
\text { adaptive capacity of } \\
\text { people and ecosystems }\end{array}$ \\
\hline $\begin{array}{l}\text { Eucalyptus } \\
\text { woodlots }\end{array}$ & -Climate regulation & $\begin{array}{l}\text {-Income generation } \\
\text {-Fuelwood and poles }\end{array}$ & $\begin{array}{l}\text { Builds resilience and } \\
\text { adaptive capacity of people }\end{array}$ \\
\hline $\begin{array}{l}\text { Agroforestry } \\
\text { (Parkland and } \\
\text { homestead) }\end{array}$ & $\begin{array}{l}\text {-Carbon sequestration } \\
\text {-Increases soil fertility } \\
\text {-Increase } \\
\text { agrobiodiversity }\end{array}$ & $\begin{array}{l}\text {-Improve food } \\
\text { security by providing } \\
\text { alternative food } \\
\text { during drought } \\
\text {-Income, fuelwood }\end{array}$ & $\begin{array}{l}\text { Builds resilience and } \\
\text { adaptive capacity of } \\
\text { people and ecosystems }\end{array}$ \\
\hline $\begin{array}{l}\text { Forest patches } \\
\text { in agricultural } \\
\text { landscapes }\end{array}$ & $\begin{array}{l}\text {-Regulate } \\
\text { micro-climate } \\
\text {-Habitat provision }\end{array}$ & $\begin{array}{l}\text {-Reduce erosion } \\
\text {-Habitat for wildlife }\end{array}$ & $\begin{array}{l}\text { Builds resilience and } \\
\text { adaptive capacity of } \\
\text { people and ecosystems }\end{array}$ \\
\hline Woodlands & $\begin{array}{l}\text {-Regulate climate } \\
\text {-Habitat provision }\end{array}$ & -Fuelwood, NTFPs & $\begin{array}{l}\text { Builds resilience and } \\
\text { adaptive capacity of } \\
\text { people and ecosystems }\end{array}$ \\
\hline $\begin{array}{l}\text { Mountain } \\
\text { forests }\end{array}$ & $\begin{array}{l}\text {-Regulate water } \\
\text { quality and quantity }\end{array}$ & $\begin{array}{l}\text {-Timber and NTFPs } \\
\text {-Fuelwood }\end{array}$ & $\begin{array}{l}\text { Builds resilience and } \\
\text { adaptive capacity of } \\
\text { people and ecosystems }\end{array}$ \\
\hline $\begin{array}{l}\text { Managed farm } \\
\text { plots }\end{array}$ & $\begin{array}{l}\text {-Agricultural } \\
\text { intensification rather } \\
\text { than expansion which } \\
\text { leads to deforestation }\end{array}$ & $\begin{array}{l}\text { Boost food } \\
\text { production and } \\
\text { enhance food } \\
\text { security }\end{array}$ & $\begin{array}{l}\text { Builds resilience and } \\
\text { adaptive capacity of } \\
\text { people and ecosystems }\end{array}$ \\
\hline
\end{tabular}

could have the co-benefits of resource and impact decoupling by increasing productivity and as the same time curbs GHG emissions [50] [51].

The results of this study showed that key policy and institutional issues to be considered for sustainable adaptation are weakly realized or inexistent at local level despite that effective and efficient policy and institutional integration could result in sustainable adaptation [52] [53]. In total, the availability and use of the five capitals, taking action collectively or individually, the strengths or weakness of climate-specific and climate-relevant capacities, awareness of the adaptation process, the types of adaptation options undertook, the livelihood evolution undertook by farmers, and how landscape production functions are managed could determine the overall adaptive capacity of farmers.

\section{Conclusion}

The general well-being and adaptive capacity of farmers to the prevailing climate change and variability impacts in the study area were mainly determined by the 
human, natural, financial, social and physical resources and how well they are looked and accessed. These resources vary across agro-ecologies. The results showed that enhancing the adaptive capacity of farmers can modulate farmers' vulnerability to climate change risks by lowering the potential impacts. To come out with tangible solutions, adaptation intervention should pass through the process of farmers' perception of climate change, their intention towards the change and their capacity to adapt the change. Indeed, climate change impacts are determined by adaptive capacity of a household to implement different adaptation strategies as the change required. This in return requires effective and efficient climate-specific and climate-relevant capacities, including boundless institutional integration. In addition, most of the income sources for a household in the study area were derived from landscape functions. This makes the management of these functions more important. Farmers have differing values for forest and agriculture in a landscape which affects adaptation outcomes. This study reminds that agricultural, forest, environmental and climate change policies should reinforce the rights of smallholders, especially of those most marginalized, to access key resources provided by landscapes functions. At the same time, development programs which pledge the sustainable use of landscapes should simultaneously enhance food security and increase smallholders' adaptive capacity in the face of climate change and variability. In order to build the adaptive capacity of households to climate change impacts as this study showed, there is a need to follow principles of ecosystem-based adaptation which is sustainable, build climate specific and relevant capacities, and enhance the availability and use of the capital resources in adaptation planning and implementation.

\section{Acknowledgements}

The authors are very grateful to African Forest Forum (AFF), Kenya and Centre for International Forest Research (CIFOR), Ethiopian Office for covering the research costs. We also add our thanks to CIFOR for covering the OAC. The authors extend their indebtedness to the interviewed households, key informants and focus group discussants as well as district levels experts to contribute their share during data collection. Last but not least our gratitude should reach to the three anonymous reviewers for their effort in reviewing and editors in editing the paper that brought an added improvement on the paper.

\section{Conflicts of Interest}

The authors declare that there is no conflict of interest.

\section{References}

[1] Sisay, T. (2016) Vulnerability of Smallholder Farmers to Climate Change at Dabat and West Belesa Districts, North Gondar, Ethiopia. Journal of Earth Science and Climate Change, 7, 365. https://doi.org/10.4172/2157-7617.1000365

[2] Abebe, Y. and Bekele, A. (2017) Vulnerability of Smallholder Farmers to Climate 
Change in the Central Rift Valley of Ethiopia: A Gender Disaggregated Approach. Ethiopian Journal of Agricultural Sciences, 27, 85-97.

[3] Yaméogo, T.B., Fonta, W.M. and Wünscher, T. (2018) Can Social Capital Influence Smallholder Farmers' Climate-Change Adaptation Decisions? Evidence from Three Semi-Arid Communities in Burkina Faso, West Africa. Social Sciences, 7, 1-20. https://doi.org/10.3390/socsci7030033

[4] Donatti, C.I., Harvey, C.A., Martinez-Rodriguez, M.R., Vignola, R. and Rodriguez, C.M. (2018) Vulnerability of Smallholder Farmers to Climate Change in Central America and Mexico: Current Knowledge and Research Gaps. Climate and Development, 11, 264-286. https://doi.org/10.1080/17565529.2018.1442796

[5] Kuwornu, J.K.M., Al-Hassan, R.M., Etwire, P.M. and Osei-Owusu, Y. (2013) Adaptation Strategies of Smallholder Farmers to Climate Change and Variability: Evidence from Northern Ghana. Information Management and Business Review, 5, 233-239.

[6] Menike, L. and Arachchi, K. (2016) Adaptation to Climate Change by Smallholder Farmers in Rural Communities: Evidence from Sri Lanka. Procedia Food Science, 6, 288-292. https://doi.org/10.1016/j.profoo.2016.02.057

[7] EPCC (Ethiopian Panel on Climate Change) (2015) First Assessment Report, Working Group II Agriculture and Food Security. Ethiopian Academy of Sciences, Addis Ababa.

[8] Agrawal, A. and Lemos, M.C. (2007) A Greener Revolution in the Making? Environmental Governance in the 21st Century. Environment. Science and Policy for Sustainable Development, 49, 36-45. https://doi.org/10.3200/ENVT.49.5.36-45

[9] Agrawal, A. (2010) Local Institutions and Adaptation to Climate Change. In: Mears and Norton, Eds., Social Dimensions of Climate Change: Equity and Vulnerability in a Warming World, World Bank, Washington DC, 173-198.

[10] Lowder, S.K., Skoet, J. and Traney, T. (2016) The Number, Size, and Distribution of Farms, Smallholder Farms, and Family Farms Worldwide. World Development, 87, 16-29. https://doi.org/10.1016/j.worlddev.2015.10.041

[11] FAO (2015) The Economic Lives of Smallholder Farmers: An Analysis Based on Household Data from Nine Countries. FAO, Rome.

[12] Deininger, K., Savastano, S. and Xia, F. (2017) Smallholders' Land Access in Sub-Saharan Africa: A New Landscape? Food Policy, 67, 78-92. https://doi.org/10.1016/j.foodpol.2016.09.012

[13] Eriksen, S., Aldunce, P., Bahinipati, C.S., Martins, R.D., Molefe, J.I., Nhemachena, C., O’Brien, K., Olorunfemi, F., Park, J., Sygna, L. and Ulsrud, K. (2011) When Not Every Response to Climate Change Is a Good One: Identifying Principles for Sustainable Adaptation. Climate and Development, 3, 7-20. https://doi.org/10.3763/cdev.2010.0060

[14] Epple, C., Wicander, S., Mant, R., Kapos, V., Rossing, T. and Rizvi, A.R. (2016) Shared Goals-Joined-Up Approaches? Why Action under the Paris Agreement, the Sustainable Development Goals and the Strategic Plan for Biodiversity 2011-2020 Needs to Come Together at the Landscape Level. FEBA Discussion Paper Developed for CBD COP 13. UNEP-WCMC, Cambridge and IUCN, Gland, 8 p.

[15] Patt, A.G. and Schroter, D. (2008) Perceptions of Climate Risk in Mozambique: Implications for the Success of Adaptation Strategies. Global Environmental Change, 18, 458-467. https://doi.org/10.1016/j.gloenvcha.2008.04.002

[16] Kebede, D. and Adane, H. (2011) Climate Change Adaptations and Induced Farm- 
ing Livelihoods. Report No. 64, the Drylands Coordination Group (DCG), Oslo.

[17] Chia, E.L., Somorin, O.A., Sonwa, D.J., Bele, Y.M. and Tiani, M.A. (2015) Forest-Climate Nexus: Linking Adaptation and Mitigation in Cameroon's Climate Policy Process. Climate and Development, 7, 85-96. https://doi.org/10.1080/17565529.2014.918867

[18] Haule, C.B.M., Mlozi, M.R.S. and Mulengera, M.K. (2013) Land Degradation and Smallholder Farmers' Response: A Case of Villages in the Southern Parts of Ludewa District, Iringa Region. Tanzania Journal of Agricultural Sciences, 12, 11-21.

[19] Kirui, O.K. (2016) Impact of Land Degradation on Household Poverty: Evidence from a Panel Data Simultaneous Equation Model. 5th International Conference of the African Association of Agricultural Economists, Transforming Smallholder Agriculture in Africa: The Role of Policy and Governance, Addis Ababa, 23-26 September 2016, 1-29.

[20] Gatzweiler, F.W. and von Braun, J. (2016) Technological and Institutional Innovations for Marginalized Smallholders in Agricultural Development. Springer, Berlin. https://doi.org/10.1007/978-3-319-25718-1_13

[21] Enbakom, H.W., Feyssa, D.H. and Takele, S. (2017) Impacts of Deforestation on the Livelihood of Smallholder Farmers in Arba Minch Zuria Woreda, Southern Ethiopia. African Journal of Agricultural Research, 12, 1293-1305. https://doi.org/10.5897/AJAR2015.10123

[22] Makate, C., Wang, R., Makate, M. and Mango, N. (2016) Crop Diversification and Livelihoods of Smallholder Farmers in Zimbabwe: Adaptive Management for Environmental Change. SpringerPlus, 5, 1135.

https://doi.org/10.1186/s40064-016-2802-4

[23] Deresa, T.T. (2010) Assessment of the Vulnerability of Ethiopian Agriculture to Climate Change and Farmers' Adaptation Strategies. PhD Thesis, University of Pretoria, Pretoria.

[24] Hameso, S.Y. (2015) Perceptions, Vulnerability and Adaptation to Climate Change in Ethiopia: The Case of Smallholder Farmers in Sidama. PhD Thesis, University of East London, London.

[25] Lemma, W.A. (2016) Analysis of Smallholder Farmers' Perceptions of Climate Change and Adaptation Strategies to Climate Change: The Case of Western Amhara Region, Ethiopia. PhD Thesis, University of South Africa, Cape Town.

[26] Amare, A. and Simane, B. (2017) Climate Change Induced Vulnerability of Smallholder Farmers: Agroecology-Based Analysis in the Muger Sub-Basin of the Upper Blue-Nile Basin of Ethiopia. American Journal of Climate Change, 6, 668-693. https://doi.org/10.4236/ajcc.2017.64034

[27] Belay, A., Recha, J.W., Woldeamanuel, T., John, F. and Morton, J.F. (2017) Smallholder Farmers' Adaptation to Climate Change and Determinants of Their Adaptation Decisions in the Central Rift Valley of Ethiopia. Agriculture \& Food Security, 6, 24. https://doi.org/10.1186/s40066-017-0100-1

[28] Asrat, P. and Simane, B. (2018) Farmers' Perception of Climate Change and Adaptation Strategies in the Dabus Watershed, North-West Ethiopia. Ecological Processes, 7, 7. https://doi.org/10.1186/s13717-018-0118-8

[29] Zegeye, H. (2018) Climate Change in Ethiopia: Impacts, Mitigation and Adaptation. International Journal of Research in Environmental Studies, 5, 18-35.

[30] CSA (Central Statistical Agency) (1994/2007) Population Censuses. Addis Ababa.

[31] CSA (2005/2016) Population Projections. Addis Ababa. 
[32] Gebreslassie, H. (2014) Land Use-Land Cover dynamics of Huluka Watershed, Central Rift Valley, Ethiopia. International Soil and Water Conservation Research, 2, 25-33. https://doi.org/10.1016/S2095-6339(15)30055-1

[33] Mekonnen, Z., Tadesse, H., Woldeamanuel, T., Asfaw, Z. and Kassa, H. (2018) Land Use and Land Cover Changes and the Link to Land Degradation in Arsi Negele District, Central Rift Valley, Ethiopia. Remote Sensing Applications. Society and Environment, 12, 1-9. https://doi.org/10.1016/j.rsase.2018.07.012

[34] Israel, G.D. (1992) Determining Sample Size. Agricultural Education and Communication Department, University of Florida, IFAS Extension, Gainesville, PEOD6.

[35] Bartlett, J.E., Kotrlik, J.W. and Higgins, C.C. (2001) Organizational Research: Determining Appropriate Sample Size in Survey Research. Information Technology, Learning, and Performance Journal, 19, 43-50. https://doi.org/10.5032/jae.2002.03001

[36] Bernard, H.R. (2006) Research Methods in Anthropology: Qualitative and Quantitative Approaches. 4th Edition, Alta Mira Press, New York.

[37] Smith, H.A. and Sharp, K. (2012) Indigenous Climate Knowledge. Climate Change, 3, 467-476. https://doi.org/10.1002/wcc.185

[38] Abate, A. and Lemenih, M. (2014) Detecting and Quantifying Land Use/Land Cover Dynamics in Nadda Asendabo Watershed, South Western Ethiopia. International Journal of Environmental Sciences, 3, 45-50.

[39] Kindu, M., Schneider, T., Teketay, D. and Knoke, T. (2015) Drivers of Land Use/Land Cover Changes in Munessa-Shashemene Landscape of the South-Central Highlands of Ethiopia. Environmental Monitoring and Assessment, 187, 452. https://doi.org/10.1007/s10661-015-4671-7

[40] Gardner, T., Godar, J. and Garrett, R. (2014) Governing for Sustainability in Agricultural-Forest Frontiers: A Case Study of the Brazilian Amazon. Discussion Brief, Stockholm Environment Institute, Stockholm.

[41] Delgado, C., Wolosin, M. and Purvis, N. (2015) Restoring and Protecting Agricultural and Forest Landscapes and Increasing Agricultural Productivity. Working Paper for Seizing the Global Opportunity: Partnerships for Better Growth and a Better Climate. New Climate Economy, London and Washington DC.

https://newclimateeconomy.report/workingpapers/wp-content/uploads/sites/5/2016 /04/NCE-restoring-protecting-ag-forest-landscapes-increase-ag.pdf

[42] Vira, B., Wildburger, C. and Mansourian, S. (2015) Forests, Trees and Landscapes for Food Security and Nutrition. A Global Assessment Report, IUFRO World Series Volume 33, Vienna, $172 \mathrm{p}$.

[43] Pan, J., Zheng, Y., Wang, J. and Xie, X. (2015) Climate Capacity: The Measurement for Adaptation to Climate Change. Chinese Journal of Population Resources and Environment, 13, 99-108. https://doi.org/10.1080/10042857.2015.1033802

[44] Munthali, K.G. and Murayama, Y. (2013) Interdependences between Smallholder Farming and Environmental Management in Rural Malawi: A Case of Agriculture-Induced Environmental Degradation in Malingunde Extension Planning Area (EPA). Land, 2, 158-175. https://doi.org/10.3390/land2020158

[45] Driscoll, D.A., Banks, S.C., Barton, P.S., Lindenmayer, D.B. and Smith, A.L. (2013) Conceptual Domain of the Matrix in Fragmented Landscapes. Trends in Ecology \& Evolution, 28, 605-613. https://doi.org/10.1016/j.tree.2013.06.010

[46] KFS (Korean Forest Service) (2015) Current State of Forests in Korea: Lessons Learned from Forest Restoration Experiences of the Republic of Korea. Daejeon.

[47] IUFRO (2016) Restoring Forest Landscapes: A “Win-Win” for People, Nature and 
Climate. http://www.iufro.org/download/file/25158/199/ws34-policy-brief_01_pdf

[48] Oliver, T.H. and Morecroft, M.D. (2014) Interactions between Climate Change and Land Use Change on Biodiversity: Attribution Problems, Risks, and Opportunities. WIREs Climate Change, 5, 317-335. https://doi.org/10.1002/wcc.271

[49] Baral, H. and Holmgren, P. (2015) A Framework for Measuring Sustainability Outcomes for Landscape Investments. Working Paper 195, CIFOR, Bogor. https://doi.org/10.17528/cifor/005761

[50] Scherr, S.J., Shames, S. and Friedman, R. (2012) From Climate-Smart Agriculture to Climate-Smart Landscapes. Agriculture \& Food Security, 1, 12. https://doi.org/10.1186/2048-7010-1-12

[51] IPCC (2013) Climate Change 2013. In: Stocker, T.F., Qin, D., Plattner, G.K., Tignor, M., Allen, S.K., Boschung, J., Nauels, A., Xia, Y., Bex, V. and Midgley, P.M., Eds., The Physical Science Basis. Contribution of Working Group I to the Fifth Assessment Report of the Intergovernmental Panel on Climate Change, Cambridge University Press, Cambridge and New York, 1535 p.

[52] Nay, J.J., Abkowitz, M., Chu, E., Gallagher, D. and Wright, H. (2014) A Review of Decision-Support Models for Adaptation to Climate Change in the Context of Development. Climate and Development, 6, 357-367.

https://doi.org/10.1080/17565529.2014.912196

[53] UNFCCC (2010) Report of the Conference of the Parties on Its 16th Session (FCCC/CP/2010/7/Add.1), Cancun, Mexico, 29 November-10 December 2010, Bonn, Germany. 